Steffen Huber

Instytut Filozofii

Uniwersytet Jagielloński

\title{
Sascha Salatowsky o filozofii socynian i Kęstutis Daugirdas o początkach socynianizmu
}

Sascha Salatowsky, Die Philosophie der Sozinianer (Filozofia socynian, 2015 )

Tytuł monografii niemieckiego badacza Saschy Salatowsky' ego $^{1}{ }^{\text {(Uni- }}$ wersytet w Erfurcie/Forschungsbibliothek Gotha) jest mylący z kilku względów. Nie zawiera historycznego przeglądu ani koncepcyjnej syntezy, ani nawet precyzyjnej definicji filozofii socynian. Zabrakło w książce ważnych postaci i omówienia całych obszarów filozofii braci polskich z Pińczowa, Rakowa, Siedmiogrodu i Amsterdamu. Autor niezbyt często podejmuje dyskusję z literaturą przedmiotu i nieraz pisze o sprawach nazbyt dobrze już zgłębionych przez nie tylko polskich historyków. Dzieło jest w pewnym stopniu niedopracowane, ale - jak sądzę - wysoce inspirujące.

W wyczerpującej wersji tytuł książki mógłby brzmieć (po polsku) np. tak: Problematyka materii, ducha i duszy oraz kwestia wiary rozumnej $w$ myśli Sonera, Völkela, Crella i Krzysztofa Stegmanna. Między renesansowym arystotelizmem a wczesnym oświeceniem. S. Salatowsky, badacz arystotelizmu oraz - w ostatnich latach - twórczości Krzysztofa Stegmanna, za punkt wyjścia swoich badań nad socynianizmem

1 S. Salatowsky, Die Philosophie der Sozinianer. Transformationen zwischen Renaissance-Aristotelismus und Frühaufklärung, Stuttgart 2015 (numery stron podawane w nawiasach odnoszą się do tego wydania). Jeżeli nie zaznaczono inaczej, tłumaczenia cytatów z recenzowanych publikacji są dziełem autora. 
obrał ratio philosophandi Aristotelica w wersji heterodoksyjnej (Simone Porzio) i ortodoksyjnej (Francisco Toletus, Benedictus Pererius). Następnie zrekonstruował ratio philosophandi Sociniana jako zogniskowaną wokół problemu wiary i rozumu w kontekście „konfesjonalizacji fizyki”. Nowatorstwa tego podejścia upatrywać należy w uwolnieniu od pozytywizmu doksograficznego i otwarciu na wewnętrzną dynamikę problemów filozoficznych napędzających myśl rakowską.

Badacz dotyka filozoficznego sedna myśli rakowskiej z nowej strony: kwestii materializmu w wymiarze fizykalnym i etycznym. Najpierw kreśli perspektywę historyczną, analizując centralne dzieła rakowian i zestawiając je z poglądami największych myślicieli wieku XVII. Następnie tworzy perspektywę systemową podobną do tej, którą w połowie XX w. przedstawił Ernst Bloch w mało znanej w Polsce, ale popularnej w Niemczech pracy pt. Avicenna und die Aristotelische Linke (Berlin 1952). S. Salatowsky stosuje identyczne kryterium jak ongiś E. Bloch, uznając, że arystotelizm ortodoksyjny daje pierwszeństwo formom inteligibilnym, a heterodoksyjny - materii wiecznej i wyposażonej w samorodną siłę wytwarzania form inteligibilnych. Jak E. Bloch szukał miejsca islamskiego arystotelizmu w genezie zachodniego materializmu, tak S. Salatowsky uważa filozofię socynian za missing link („materializm metafizyczny”) w procesie wiodącym od heterodoksyjnego arystotelizmu renesansowego do materializmu mechanistycznego (s. 70-90, 339-345). Niestety, Autor nie udokumentował dróg recepcji, być może dlatego, że pierwsi antytrynitarze pochodzili z północnych Włoch, czyli z ojczyzny arystotelizmu heterodoksyjnego, i stąd sprawa wydawała mu się przesądzona. Obie perspektywy, historyczna i systemowa, splatają się nieraz w petitio principii. Zdarzyło się to już E. Blochowi. Problem wszak nie jest zasadniczy: wystarczy nieco doprecyzować ustalenia S. Salatowsky'ego, aby móc skorzystać z zalet tej perspektywy badawczej.

$\mathrm{Z}$ wielokrotnie badaną relacją rozumu i wiary w myśli socynian Badacz zestawia więc problem materializmu i naturalizmu, ukazując proprium socyniańskiej fizyki i metafizyki. Socynianie połączyli kreacjonizm z preegzystencją materii, czego owocem była unikalna teoria podwójnego stworzenia, w ocenie Autora najpełniej wyrażona przez Krzysztofa Stegmanna (s. 344, pkt 8). Zgodnie z tą teorią $\mathrm{w}$ pierwszym akcie stworzenia, niewspomnianym explicite, ale założonym implicite w Biblii, Bóg stworzył materię pierwszą. W drugim akcie, opisanym w Księdze Rodzaju, Bóg, zaczynając od rozdzielenia nieba i ziemi, stworzył formy inteligibilne. Stąd cechą fizyki 
i metafizyki socynian jest, zdaniem S. Salatowsky’ego, „materializm metafizyczny" w odróżnieniu od starożytnego materializmu atomistycznego oraz nowożytnego materializmu mechanistycznego (s. 344 i passim). Formy inteligibilne otrzymują tu wysoki status ontologiczny, a chwilowo nawet prymat nad materią. Jednak okazuje się ona na tyle silna, że sama rozwija coraz wyższe formy oraz zdolności poznawcze. $Z$ tego powodu formy stanowią zmienne przypadłości niezmiennego podłoża materialnego. Wraz z taką "myślącą materią” powstaje, jak podkreśla Autor, „straszna” alternatywa dla teleologicznej teologii przyrody (s. 306). Ponadto ukazuje on, że arystotelizm był bardzo użytecznym zasobem precyzyjnej terminologii dla całej filozofii XVII stulecia, kiedy z Arystotelesowskiej kosmologii pozostało już niewiele. Niestety interpretacja ta jest spójna tylko w odniesienia do fizyki socynian. Gorzej z ontologią Gottfrieda Wilhelma Leibniza, którą S. Salatowsky opisuje bez uwzględnienia aspektów modalnych (s. 319-320 i passim). Również systemy innych wielkich myślicieli XVII w. są tu prezentowane mało precyzyjnie, a porównanie ich z myślą socynian nastręcza trudności (szkoda, bo na s. 335 Autor naszkicował ciekawe zestawianie thinking matter późniejszych angielskich materialistów $\mathrm{z}$ „materią tendencyjnie myślącą” socynian).

Po materializmie (meta)fizycznym socynian drugą centralną kwestią w monografii S. Salatowsky'ego jest „antropologia”, która niekiedy sprowadza się tu do teorii duszy $\mathrm{w}$ aspekcie czysto strukturalnym oraz do problemu materialności duszy, względnie ducha. $Z$ pola widzenia znikają epistemologiczne, etyczne i polityczne aspekty antropologii, m.in. te związane $\mathrm{z}$ rakowską teorią tolerancji. Po raz kolejny tytuł połączony z niezbyt szczęśliwymi uproszczeniami, tym razem dotyczącymi antropologii szesnastowiecznej i arystotelesowskiej teorii duszy, przysłania ciekawy przekaz Autora. Udało mu się bowiem wykazać, że stworzona przez Jana Crella i Krzysztofa Stegmanna późnosocyniańska teoria duszy zakorzeniona jest w greckim rozumieniu psychologii jako jednym z obszarów filozofii przyrody, czyli fizyki (s. 347-458, zwł. s. 419-427). W centrum tej teorii znajdują się następujące problemy: śmiertelność duszy, jej bycie materią lub/i formą (w tym formą kształtującą ciało [forma informans]), ontologiczny status duszy jako całości oraz jej poszczególnych części lub/i funkcji. Dzięki zakorzenieniu w historii problemów filozoficznych oryginalne poglądy Crella i Stegmanna stają się tu plastyczne i żywe. Zestawienie ich z poglądami Lutra może się wydawać mało inspirujące dla polskiego czytelnika, ale książka jest kierowana do publiczności niemieckiej, która 
dzięki temu zyskuje lepszy obraz miejsca, jakie socynianie zajmowali na intelektualnej mapie wczesnej nowożytności.

W szczególnie sugestywny sposób Autor pokazuje współzależność dwóch dziedzin filozofii w myśli Crella: w (meta)fizyce rakowski teolog podnosił status materii kosztem formy, a równolegle w psychologii status ducha kosztem duszy (s. 400-412, zwł. s. 410). To dzięki swej materialności duch jest substancją i trwa po śmierci człowieka, tzn. po śmierci nie tylko ciała, ale i duszy. Na tym tle Crell sugerował, że materialny duch człowieka może po jego śmierci być przechowywany przejściowo w obcym ciele, aby przetrwać do czasu zmartwychwstania (s. 404). Koncepcja Crella prezentuje się tu spójnie, a wartość analiz S. Salatowsky'ego polega na tym, że odsłaniają rodzące się tendencje i trudno uchwytną, lecz istotną „atmosferę” wokół myśli socyniańskiej.

Najważniejsze w rozdziale „antropologicznym” jest omówienie koncepcji Krzysztofa Stegmanna. Autor eksponuje wnioski, jakie Stegmann wyciągnął explicite w odróżnieniu od jego poprzedników, którzy poprzestawali na sugestiach. Dusza okazuje się tu przypadłością czy to ludzkiego ciała, czy to człowieka jako całości (,subtracto corpore tanquam subjecto non amplius existit”, s. 420). Stąd nawet Bóg nie może uczynić duszy substancją, czyli zbawić jej w oderwaniu od ludzkiego ciała. Podobnie jak Crell, Stegmann nie umieszcza ducha $\mathrm{w}$ pojętej po platońsku amaterialnej sferze psyche, lecz w sferze physis rozumianej zgodnie z założeniami heterodoksyjnego arystotelizmu: duch jest tu substancją, i to w mocnym sensie substancji niezniszczalnej, o ile jest pars materiae (s. 425). Ów „mortalizm psychologiczny” nie oznacza wszak, jak słusznie podkreśla S. Salatowsky, deprecjacji człowieka, gdyż ten poznaje i działa nie jako dusza, lecz jako określona przez duch całość ciała, duszy i ducha.

Stosowne analizy Autora wnoszą sporo do interpretacji myśli socyniańskiej. Nieco gorzej jest w kwestii odrębnych funkcji duszy: czy świadczą o istnieniu ontycznie odrębnych części? Wbrew temu, co sugeruje Badacz, problem ten bynajmniej nie powstał w XVI w. wskutek reformacyjnej „antropologizacji myśli filozoficznej”" i nie

2 S. Salatowsky, op. cit., s. 347. Używane tu pojęcie antropologii pochodzi z prac Oda Marquarda (z początku lat siedemdziesiątych XX w.), w których służyło poszerzeniu perspektywy, wówczas jeszcze skupionej wyłącznie na antropologii dwudziestowiecznej (Max Scheler, Helmuth Plessner), o myśl Kanta i filozofię wczesnonowożytną. Ze względu na tę specyficzną funkcję Marquardowskie pojęcie antropologii wydaje się niezbyt adekwatne do badań nad relacjami łączącymi filozofię XVII w. z dorobkiem poprzednich epok. 
został na nowo odkryty przez socynian, lecz ma rodowód antyczno-średniowieczny, czego wymownym świadectwem są w Polsce choćby typowe dla via communis rozważania Pawła z Worczyna (1383-1430) nad psychologią filozoficzną Jana Burydana ${ }^{3}$. S. Salatowsky sprowadza więc wielowątkowy racjonalizm socynian do tradycyjnej (w sensie arystotelizmu heterodoksyjnego), ale pozbawionej kontekstu historycznego ontologii duszy. Tymczasem wiele łączy filozofię socyniańską $\mathrm{z}$ siedemnastowieczną filozofią podmiotu, postrzegającą byt z wnętrza podmiotu poznającego. I chyba nie wszystkie reakcje socynian na najnowsze systemy filozoficzne wypadały tak jednoznacznie negatywnie jak odpowiedź Jana Wolzogena na psychologię Kartezjusza (s. 434-446). W XVII w. filozofowie nie mogli już pytać, czy rozum jest zgodny z wiarą i odpowiadać na to pytanie afirmatywnie wyłącznie na podstawie (meta)fizycznej narracji o wspólnym pochodzeniu rozumu i wiary z tak czy inaczej pojętego praźródła. Wówczas trzeba było używać nowych filozoficznych technik, łączących introspekcję z racjonalną spekulacją dotyczącą wszystkiego, co pozamentalne i transcendentne, i krytycznie spoglądać na starą scholastykę nawet wtedy, gdy broniło się tradycyjnych motywów metafizycznych. Pomiędzy tymi biegunami poruszali się socynianie w epistemologii, co miało swoje konsekwencje dla szerzej pojętej antropologii, etyki i polityki, np. w argumentacji Crella, że conscientia jednego podmiotu przejawia się w tolerowaniu conscientia drugiego, w tym koniecznie jego conscientia erronea, przy założeniu, że heretycy, jeśli błądzą, to błądzą bezwiednie. Stąd płynie wniosek Crella, że przemoc jest zawsze szkodliwa, a jedynie wzajemna tolerancja, oparta na wiedzy o ludzkich słabościach, gwarantuje pokój społeczny ${ }^{4}$. Podsumowująca szkołę rakow-

3 Paulus de Worczin, Quaestiones super tres libros „De anima”, ed. Z. Kuksewicz, Wrocław 1969 (Materiały i Studia Zakładu Historii Filozofii Starożytnej i Średniowiecznej. Seria A. Materiały do Historii Filozofii Średniowiecznej w Polsce, t. 10).

4 J. Crell, O wolność sumienia (Vindiciae pro religionis libertate), tł. I. Lichońska, wstęp i przyp. Z. Ogonowski, oprac. tł. L. Chmaj, D. Gromska, W. Wąsik, Warszawa 1957, rozdz. 2 „Posse catholicos salva conscientia libertatem religionis haeriticis concedere et de securitate illis cavere”, zwł. s. 20-21: „At qui hodie sunt haeretici, ii nesciunt se adversus Dei legem [- ] quicquam agere aut credere; et si scirent, sententias de religione suas abjicerent”; s. 38-39: „quisque se putat optime de religione sentire ac credere et catholicus non minus haeretico est haereticus, quam haereticus catholico. Itaque haereticus magistratus alitere facere non poterit [- $]$ quam ut [- $]$ catholicos omnino pellendos statuat. Hoc si catholicis displiceat, ne placeat etiam ipsis haereticos imbecilliores e rebuspublicis suis pellere". 
ską Religio rationalis Andrzeja Wiszowatego jest już wyraźnie filozofią podmiotu. Jej centralne tezy opierają się na racjonalno-krytycznej introspekcji i analizie transcendentalnych aspektów poznania zamiast na obiektywistycznej ontologii duszy, ducha bądź rozumu ${ }^{5}$. O tym wszystkim S. Salatowsky nie wspomina, sprawiając pewne rozczarowanie tym, którzy chcieliby odczytać dosłownie zapowiedź syntezy filozofii socynian.

Podsumowując, za najbardziej udane w recenzowanej pracy niemieckiego Badacza uznać należy aspekty dynamiczne, związane z nową fizyką na styku z metafizyką, nauką empiryczną i religią, otwierające ciekawą perspektywę dla wszystkich, którzy pragną zinterpretować pisma socynian z perspektywy filozofii. Autor prezentuje elementy arystotelizmu $\mathrm{w}$ dyskursie antyscholastycznym, zwracając uwagę na to, że dzięki nim włoska i rakowska heterodoksja mogła zrezygnować z apologetycznego holizmu (meta)fizycznego i na nowo uznać starogreckie aporie, aby ostatecznie stworzyć z wielką śmiałością własną, rakowską „fizykę konfesyjną”, połączoną z teorią rozumu i wiary (s. 77-82). Pod tym względem monografia spełnia $z$ naddatkiem obietnicę zawartą $\mathrm{w}$ tytule, wskazuje bowiem miejsce socynian w historii filozofii europejskiej. I tej zasługi Autora nie umniejsza fakt, że udało mu się to "tylko" - lub raczej „aż” - w odniesieniu do jednej z tradycyjnie podstawowych kontrowersji wszelkiej filozofii, bez uwzględniania np. myśli społecznej. Ta bowiem jest już bogato udokumentowana.

Jak wskazano, w książce S. Salatowsky'ego dostrzegalne są pewne niedociągnięcia warsztatowe. Wynikające z nich nieścisłości doksograficzne dotyczą także siedemnastowiecznego kontekstu filozofii socynian. Irytująca jest np. rekonstrukcja stosunku Gottfrieda Wilhelma Leibniza do socynian wraz z oceną, że wątpliwości podnoszone przez niemieckiego myśliciela wobec materializmu Stegmanna są „w całości słabo uzasadnione" (s. 345, pkt 9). Podobne niezręczności pojawiają się w partiach poświęconych Johnowi Locke’owi (fizyka: s. 327-339, teoria duszy: s. 446-453). Wspomnieć należy wreszcie o dwóch problemach, które dotyczą całej monografii. Pierwszy wiąże się z proponowanym tu rozumieniem arystotelizmu. Jest ono zbyt szerokie

5 A. Wiszowaty, O religii zgodnej z rozumem czyli Traktat o postugiwaniu się sądem rozumu takze $w$ sprawach teologicznych $i$ religijnych / Andreae Wissowati religio rationalis seu. De rationis iudicio in controversiis etiam theologicis ac religiosis adhibendo tractatus, tł. E. Jędrkiewicz, wstęp i przyp. Z. Ogonowski, Warszawa 1960. 
i pod względem systemowym obejmuje niektóre ogólne cechy filozofii greckiej (np. dążenie do wiedzy pojętej jako perfectio animae), pod względem historycznym zaś zostają doń włączone - bez komentarza Autora - nurty powszechnie traktowane jako niezależne od arystotelizmu czy wręcz mu przeciwstawne, np. filologicznie zainspirowana hermeneutyka filozoficzna wczesnonowożytnych humanistów, którzy bez wątpienia wywarli wpływ na filozofię socyniańską. Wskutek tego najistotniejsze tezy $S$. Salatowsky'ego, choć opierają się na ciekawych, intuicyjnych spostrzeżeniach, nie zawsze zyskują solidne oparcie w analizach. Drugi problem sytuuje się na płaszczyźnie metahistorycznej. Wydaje się, że rozpoznanie go pozwala zarówno opisać słabą stronę monografii, jak i docenić jej niezwykłą wartość. Otóż Autor posługuje się linearnym paradygmatem historii intelektualnej, w którym to, co wcześniejsze z konieczności „wpływa” na to, co późniejsze. Nie ma tu równoległych linii rozwojowych ani zapętlających się powrotów, nie powstają sieciowe wspótzależności, a stąd bierze się np. wątpliwa ocena socynian jako „pierwszych materialistów” wraz z sugestią, że angielscy materialiści nie mogliby opracować swoich koncepcji bez socynian (s. 345). Czytelnik powinien przyjąć cenne obserwacje S. Salatowsky'ego i samodzielnie wpleść je w bardziej zróżnicowaną strukturę współzależności filozoficznych koncepcji na progu nowożytności. Jest to możliwe dzięki temu, że Autor drobiazgowo rekonstruuje problemy leżące u podstaw filozofii socyniańskiej.

Kęstutis Daugirdas, Die Anfänge des Sozinianismus (Początki socynianizmu, 2016)

Podczas gdy Sascha Salatowsky skupia się na filozofii, Kęstutis Daugirdas - uczony pochodzący z Litwy i pracujący na Uniwersytecie Jana Gutenberga w Moguncji - bada socynianizm w perspektywie teologicznej ${ }^{6}$. Obaj autorzy wskazują w przedmowach na komplementarny charakter swoich prac. S. Salatowsky wymienia pracę K. Daugirdasa jako "swego rodzaju teologiczny odpowiednik" własnej monografii (s. V), którą litewski Badacz uznaje z kolei za "fundamentalne studium" (s. 9). W metodach obu uczonych widać jednak zasadnicze różnice. K. Daugirdas przyznaje się do inspiracji teorią aktora

${ }^{6}$ Jako podstawa do niniejszych rozważań służy studium: K. Daugirdas, Die Anfänge des Sozinianismus. Genese und Eindringen des historisch-ethischen Religionsmodells in den universitären Diskurs der Evangelischen in Europa, Göttingen 2016 (numery stron podawane w nawiasach odnoszą się do tego wydania). 
i sieci (actor-network theory, s. 42). Narracja teologiczno-historyczna jest bogata i zarazem bardzo spójna. Wątpliwości budzą rozważania z pogranicza z filozofii, szczególnie w odniesieniu do ontologii, jednak bardziej w terminologii aniżeli w samych analizach (zob. niżej).

Książka omawia okres od działalności Fausta Socyna poprzez wczesną recepcję socynianizmu w krajach niemieckojęzycznych po dwie paradygmatyczne reakcje na socynianizm w XVII stuleciu: ostrożną afirmację niderlandzko-fryzyjskich remonstrantów i (niepozbawioną respektu) dezaprobatę luterańskich neoscholastyków z uniwersytetów w Jenie i Wittenberdze. Wywód zaczyna się od omówienia literatury badawczej, z którą Autor prowadzi intensywny dialog. Rozdział pt. „Przegląd historii badań. Ujęcie problemu” podzielono na partie odpowiadające poszczególnym krajom. W przypadku Europy Środkowo-Wschodniej wydaje się to nieco sztuczne. Tutejsi badacze czytają prace zagraniczne raczej bez względu na język, z wyjątkiem może węgierskiego i litewskiego (i właśnie takich prac brakuje również u K. Daugirdasa). Jeśli jednak spojrzeć w odwrotnym kierunku, widać, że Autor ma rację: prace napisane w językach wschodnioeuropejskich są rzadziej recypowane na Zachodzie. Trafiony wydaje się postulat zbadania dorobku „pierwszych wpływowych popularyzatorów myśli Fausta Socyna w Polsce" (s. 39), tym bardziej że Autor spełnia go natychmiast w osobnym podrozdziale (s. 178-239).

Materialnym fundamentem badań K. Daugirdasa jest przede wszystkim dorobek Fausta Socyna, uzupełniony dziełami jego naśladowców. Różnice międzypokoleniowe, np. w kwestii teologii naturalnej, uchodzą tu za zjawiska wtórne. Można polemizować z takim ujęciem, w którym socynianizm sprowadza się niejako do samego Socyna. Warto jednak pamiętać, że celem Badacza nie jest rekonstrukcja myśli socyniańskiej jako takiej, lecz prześledzenie jej wczesnej recepcji na uniwersytetach zachodnich protestantów. Atrakcyjność socynianizmu dla tych kręgów wynikała, jak pokazuje Autor, nie tyle z filozoficznej oryginalności, ile z religijnego autentyzmu czerpiącego siłę ze zradykalizowanej luterańskiej zasady scriptura sui ipsius interpres i przemodelowanej przez Socyna erazmiańskiej hermeneutyki (s. 59, przyp. 26). Na tym tle K. Daugirdas dopatruje się trzech głównych osiągnięć socynianizmu. Jest to, po pierwsze, „historyzacja wiary na podstawie filologii”, po drugie - „krytyczne skoordynowanie wiary z zasadami racjonalności etyczno-prawnej” i po trzecie - ponadkonfesyjny „historyczno-etyczny model religii, który odłącza poszukiwanie sensu od wiedzy o byciu" (s. 40 i passim). Ta ostatnia, 
podstawowa teza Autora zostanie omówiona niżej. Warto podkreślić już w tym miejscu, że jest ona przekonująca pod względem teologicznym, niekoniecznie natomiast filozoficznym.

Rozdział o Fauście Socynie przynosi pod względem merytorycznym raczej konwencjonalny, ale niezwykle klarowny wykład kanonicznych motywów socynianizmu wraz z procesem ich popularyzacji. Wychodząc od interpretacji prologu do Ewangelii św. Jana („na początku było objawienie"), Badacz przedstawia najpierw koncepcję podwójnego czasu Starego i Nowego Testamentu, zasadę munerystyczną i rozumienie biblijno-teologicznego wyrażenia „boski” jako nomen appellativum zamiast, jak w tradycyjnej chrystologii, nomen proprium (s. 62). Pokazując konsekwencje dogmatyczne, odsłania różnicę między racjonalizmem Fausta Socyna, który stosował zasady rozumu implicite, a racjonalizmem siedemnastowiecznym, przedstawiającym i stosującym swoje reguły explicite, ofensywnie i dogmatotwórczo (s. 67). W zasadniczej kwestii chrystologicznej (mediator) Autor zakorzenia myśl Socyna nawet we wczesnym średniowieczu (Piotr Abelard, s. 79), a także w mistyce (Tomasz à Kempis, s. 82) i wreszcie w sceptycyzmie renesansowym (Sebastian Castellion, s. 71). Zabieg ten jest uzasadniony, ponieważ w kontekście socynianizmu pojęcie racjonalizmu powinno zawierać właśnie takie elementy, które dopiero pod wpływem puryzmu siedemnastowiecznych systemów filozoficznych zaczęły uchodzić za tak różnorodne, że aż wzajemnie się wykluczające. Dotyczy to zwłaszcza związku mistyki i sceptycyzmu. Z ustaleń K. Daugirdasa wynika, iż socynianie mieli do nich przynajmniej tak samo blisko jak do angielskich deistów i materialistów, o których wspomina S. Salatowsky.

W sprawie śmiertelności człowieka, jego duszy i ducha K. Daugirdas potwierdza analizy S. Salatowsky' ego, eksponując związek między mortalizmem, kreacjonizmem a jurydyczną teorią sprawiedliwości: niemożliwość zmartwychwstania człowieka (przynajmniej w aspekcie psychofizycznym, a raczej w ogóle) stanowi prostą konsekwencję tego, że Bóg stworzył człowieka jako istotę skończoną, co harmonijnie współbrzmi z przekonaniem, iż ludzkie winy i zasługi mają wymiar radykalnie indywidualny, wykluczający przeniesienie winy starotestamentowego Adama na obecnie żyjących (s. 99-113).

Krótki podrozdział o „historycznie niezawodnym świadectwie Biblii” zawiera analizę biblizmu Socyna na tle filozoficznej hermeneutyki. Pozwala to lepiej zrozumieć połączenie pozornie prostej zasady historycznej autentyczności tekstów biblijnych z subtelną 
hermeneutyką socynian, która - według K. Daugirdasa - pozostaje zakorzeniona w myśli św. Augustyna (s. 114) i jednocześnie otwiera się na wszelakie nowości własnej epoki.

Bardziej szczegółowe jest omówienie relacji łączącej człowieka z Bogiem. K. Daugirdas zestawia ten zasadniczy element socynianizmu z fizyką i metafizyką (śmiertelność), teologią klasyczną (grzech pierworodny) i reformowaną (predestynacja, wolna wola), wreszcie - poprzez problem istnienia $\mathrm{w}$ czasie $\mathrm{i}$ istnienia czasu $-\mathrm{z}$ ontologia (s. 132-153). Płynące stąd tezy interpretacyjne, według których Socyn „relację Bóg - człowiek przekształca w relację człowiek - Bóg” i przesuwa główny akcent $\mathrm{z}$,teologicznego poglądu na świat i próby wyjaśnienia rzeczywistości” w stronę etyki (s. 152-153), należy koniecznie czytać na tle całości analiz K. Daugirdasa.

Rozdział o Socynie zamykają uwagi o prawie jako źródle ważnych rozwiązań teologicznych. Autor pokazuje tu, jak zasada niekarania nikogo za cudze czyny, połączona z zakazem karania nieproporcjonalnego do zawinienia, rodziły teologematy o niemożliwości grzechu pierworodnego i wiecznego potępienia (s. 154).

W takich to ramach należy rozumieć „historyczno-etyczny model religijności”, który, jak dowodzi Badacz, określa rolę socynian w drodze od "późnoszesnastowiecznych teorii inspiracji werbalnej” do historycznej egzegezy biblijnej Hugona Grocjusza (s. 129, 434 i passim). Ramy teologiczne tego modelu są skoncypowane precyzyjnie i spójnie. Pewnym problemem może być cechująca K. Daugirdasa dążność do klarownej terminologii teologicznej kosztem tej filozoficznej. Wiele koncepcji teologicznych opiera się na filozoficznej ontologii i często są to właśnie koncepcje ortodoksyjno-apologetyczne. Przykładem może być zontologizowana $\mathrm{w}$ duchu arystotelesowsko-tomistycznym teologia potrydencka, ale także - o czym obszernie pisze Autor - protestancka neoscholastyka zwalczająca socynianizm (s. 488-536). Patrząc z punktu widzenia historii teologii, można więc łatwo uznać, że teologie ortodoksyjne w naturalny sposób wiążą się nie tyle z konkretnymi ontologiami, zwykle o proweniencji mniej lub bardziej platońskiej, ile z ontologią jako taką (K. Daugirdas mówi wtedy o zadawaniu pytań o sens bycia), podczas gdy teologie heterodoksyjne, w tym socyniańska, w równie naturalny sposób zamykałyby się na ontologię i wiązały $\mathrm{z}$ innymi dziedzinami filozofii, np. z etyką. I właśnie ta sugerowana czasem przez K. Daugirdasa dychotomia pojęciowa może dać niezamierzone efekty. Nieprawdą byłoby bowiem twierdzenie, że socynianie negowali ontologię jako taką lub choćby jej rolę dla teologii. 
Dowodów na to, iż mieli oni swoją ontologię dostarcza zresztą sam Autor, analizując ich fizykę, metafizykę, teorię duszy i koncepcję czasu. Co więcej, dokładnie pokazuje on funkcje pełnione przez owe elementy ontologii w teologii socyniańskiej. Ontologiami są bowiem również materialistyczna fizyka i metafizyka zainspirowana fizjologią presokratejską czy fizyką arystotelesowską. Wreszcie - jak w przypadku socyniańskiej negacji grzechu pierworodnego - do tworzenia ontologii może zachęcać etyka, w szczególności problem sprawiedliwości, który od czasów presokratejskiej dike i platońskiej dikaiosyne jest nierozerwalnie połączony z myśleniem o bycie.

Zrekonstruowana przez K. Daugirdasa socyniańska argumentacja na rzecz wolnej woli ma więc charakter etyczny, jednak nie w sensie pełnej autarkii metodologicznej, lecz właśnie jej typowo filozoficznego zespolenia z ontologią i epistemologią. Zasadniczy argument Socyna brzmi: byt konstytuuje się w czasie i przez czas; to, co nie istnieje nie ma żadnych właściwości, a zatem coś, co dopiero zaistnieje (albo i nie) nie może być znane nikomu, w tym Bogu (s. 149). Na tym ontologicznym tle Socyn zanalizował problem wolnej woli człowieka inaczej niż Erazm z Rotterdamu, który potrzebował jeszcze - również ontologicznego - argumentu z imago Dei. Jedynym ograniczeniem wolnej woli człowieka jest, według Socyna, warunek, że to Bóg, a nie człowiek, decyduje o losach świata (s. 148-149). Te i podobne analizy K. Daugirdasa pokazują, że w „historyczno-etycznym modelu religijności”, pomimo tezy generalnej, głoszącej rzekome odejście socynian od używania ontologii w kwestiach teologicznych (theologische Seinserklärung), wciąż jest miejsce na prawdziwą ontologię.

Rozdział poświęcony protagonistom wczesnego socynianizmu zaczyna się od krótkiego przedstawienia kontekstów siedmiogrodzkiego i polsko-litewskiego. Następnie Autor realizuje własny postulat omówienia dzieł najważniejszych polskich zwolenników socynianizmu: Piotra Statoriusa Starszego, Andrzeja Wojdowskiego i - przede wszystkim - Hieronima Moskorzowskiego (s. 178-239). Najwięcej źródeł dotyczy obszaru niemieckojęzycznego, na którym działali Krzysztof Ostorodt, Johannes Völkel i Walenty Szmalc (s. 239-340). Temu ostatniemu K. Daugirdas poświęca najwięcej uwagi, koncentrując się m.in. na jego argumentacji w sprawie śmiertelności ludzkiej duszy (anima) i nieśmiertelności ludzkiego ducha (spiritus autem ad eum redit, qui eum dedit, nempe Deus, s. 295, przyp. 597). Widać tu, że mortalizm socynian im dalej był od Rakowa, tym bardziej stawał się chwiejny, a popularyzatorzy mieli wielkie opory przed 
ujawnianiem jego ostatecznych konsekwencji. Dla historii filozofii polskiej ciekawy jest także opis polemiki między Szmalcem a wileńskim profesorem Marcinem Śmigleckim, cenionym w Europie logikiem i epistemologiem, wrażliwym na kwestie ontologiczne (ens rationis), w Polsce występującym jako polemista socynian (s. 314-332). Rozdział kończy się wywodem o roli socynian we wczesnej fazie rozwoju historycznej egzegezy biblijnej (s. 332-340).

Rozdział czwarty, traktujący o miejscu historyczno-etycznego modelu $\mathrm{w}$ dyskursie uniwersyteckim zachodnich protestantów, rozwija się według niezwykłej dramaturgii. Pierwszy podrozdział przedstawia w kluczu geograficznym (Zurych, Heidelberg, Wittenberga, Królewiec) pierwsze reakcje na unitariański wydźwięk nauk Socyna (s. 342-374). Drugi podrozdział poświęcono znanemu heidelberskiemu profesorowi teologii Davidowi Pareusowi, a w szerszym sensie - elitom uniwersyteckim (s. 375-392). Trzeci prezentuje sylwetkę Konrada Vorstiusa, który działał w Nadrenii i uwikłał się w skandal wokół wydania traktatu Socyna pt. De auctoritate sacrae scripturae w drugiej dekadzie XVII w. (s. 392-438). Wreszcie w czwartym i piątym podrozdziale, zatem w długiej, końcowej partii monografii (s. 439-536), Autor dowodzi, jak fascynującym zajęciem może być historia intelektualna. W czwartym podrozdziale pokazuje związki remonstrantów w Holandii i Fryzji z socynianizmem. Piąty podrozdział traktuje o profesorach teologii w luterańskich uniwersytetach w Jenie i Wittenberdze, którzy pisząc polemiki przeciw socynianom, częściowo ulegali fascynacji i rozpoczynali z nimi dialog o paradygmatach hermeneutycznych. Autor wprowadza tu w świat dwuznacznych relacji intelektualnych między luteranizmem a socynianizmem, w którym obszerne cytaty przytaczane z dzieł socynian nie tylko stanowiły źródło solidnej wiedzy dla studentów w Wittenberdze i Jenie, ale także inspiracji - ni to chcianej, ni to niechcianej - dla samych profesorów-polemistów. W taki sposób w ostrej wymianie argumentów wytwarzał się stopniowo wspólny model racjonalności (s. 523). K. Daugirdas podsumowuje to dwoma zdaniami, które warto zacytować w pełni, zdaje się bowiem, że skojarzenia z Fenomenologia ducha Hegla nie są tu przypadkowe:

Z jednej strony [teolodzy luterańscy] intensywnie rozpracowywali propagowany przez socynian historyczno-etyczny model religii, przygotowując studentów uniwersytetu w Wittenberdze do zróżnicowanej oceny podstawowych elementów socynianizmu i wyposażając ich we wzorce argumentacji, 
które miały służyć skutecznej walce z socynianizmem. Z drugiej zaś w tym procesie kreowania wielowarstwowych odniesień do myśli socyniańskiej poszczególne jej elementy zaczęły się łączyć z przeciwstawnymi elementami teologii luterańskiej jako ze swoimi antytezami, tworząc z nimi jedność, w której różnorodne poglądy teologiczne pozostawały już na trwałe splecione we wzajemnych relacjach i bywało, że metody historyczno-racjonalne obu stron skutkowały zbliżonym podejściem do problemów (s. 530).

Te analizy modeli racjonalności rozwijających się we wzajemnym historycznym oddziaływaniu stanowią podstawę postawionej w zakończeniu tezy, zgodnie z którą „akcentowanie [przez socynian i niektórych wittenberskich luteranów - S.H.] normatywności rozumu w sprawach religijnych stanowi zapowiedź kwestii fundamentalnej dla zbliżającego się oświecenia, mianowicie kwestii autonomicznej jednostki ludzkiej kierującej się uniwersalną racjonalnością i zdolnej do samostanowienia w religijno-moralnych aspektach swej egzystencji" (s. 536). Po lekturze monografii K. Daugirdasa takie hasła, które łatwo stają się stereotypowe, odzyskują koncepcyjną i historyczną głębię.

Podsumowani e

Dzieła Saschy Salatowsky'ego i Kęstutisa Daugirdasa uzupełniają się na kilka sposobów. Pierwszy Badacz dostarczył sporo wnikliwych analiz podstawowych aspektów filozoficznych, przede wszystkim tych, w których łączą się fizyka, metafizyka i teoria duszy. Jego rekonstrukcja problemu materii, w tym materialności ludzkiej duszy i Boga, otwiera nowe perspektywy badawcze. Słabymi stronami jego monografii są brak dialogu z literaturą przedmiotu, niezbyt spójna konstrukcja rozdziałów i tytuł, który obiecuje zbyt wiele i jednocześnie przemilcza zalety dzieła. Druga recenzowana pozycja jest wzorcową monografią historyczną, opartą na dobrze dobranym, doskonale uporządkowanym i zawsze wyrazistym materiale źródłowym. Jeśli poszukać w niej słabszych stron, a trzeba to robić nieco na siłę, to można je znaleźć w terminologii filozoficznej. Obie książki różnią się więc poziomem dopracowania, ale są równie przydatne, jeśli uwzględnić ich specyficzną, niepolską perspektywę. Książka S. Salatowsky'ego stanowi źródło istotnych inspiracji dla (re)interpretacji myśli socynian, a studium K. Daugirdasa jest obszernym i solidnym kompendium z zakresu historii teologii. 